\title{
Development and evaluation of a solid-phase enzyme immunoassay based on Andes hantavirus recombinant nucleoprotein
}

\author{
P. J. PADUlA, C. M. ROSSI, M. O. DELLA VALLE, P. V. MARTÍNEZ, S. B. COLAVECCHIA, \\ A. EDELSTEIN, S. D. L. MIGUEL, R. D. RABINOVICH and E. L. SEGURA
}

Servicio de Biología Molecular, Dpto de Virología, Instituto Nacional de Enfermedades Infecciosas, ANLIS ‘Dr Carlos G Malbrán', Av. Velez Sarsfield 563, 1281 Buenos Aires, Argentina

\begin{abstract}
Hantavirus pulmonary syndrome (HPS) with high mortality rate has been reported in five countries in South America. Rapid accurate methods are important both for monitoring acute infections and for epidemiological studies. The Andes virus nucleoprotein amino acid sequence has a high identity percentage compared with other sequences of this region and has been chosen for the development of diagnostic reagents. Andes nucleoprotein expressed in Escherichia coli was applied as antigen in IgG, IgA and $\boldsymbol{\mu}$-capture IgM enzyme-linked inmunosorbent assays (ELISAs). An evaluation of this reagent was conducted to establish its usefulness for differential diagnosis of HPS and seroprevalence studies. Samples from 135 reverse transcription (RT)-PCR-confirmed HPS cases, 77 individuals with other respiratory infections and 957 healthy inhabitants from endemic and non-endemic areas were analysed. The hantavirus-infected patients had an early and strong IgM, IgG and IgA serum antibody response, in most of the cases as early as 1,7 and 1 days following onset of symptoms, respectively. IgM and IgG detection showed a specificity and sensitivity of $100 \%$. Andes-specific IgM antibodies were found in all patients in the first available sample, which remained detectable for at least 43 days. Specific IgA antibodies were also detected in saliva of patients with acute HPS. The short duration of the disease and the risk for contacts due to person-to-person transmission of Andes virus necessitate the use of highly sensitive tests which might lead to earlier detection of infected people and improve the treatment and management of patients with HPS.
\end{abstract}

\section{Introduction}

Hantaviruses cause $>150000$ human infections worldwide annually, associated with haemorrhagic fever with renal syndrome (HFRS) [1]. In A merica, hantavirus pulmonary syndrome (HPS) with a high mortality rate has also been described [2]. By the first quarter of 1998, a total of 231 HPS cases had been reported in five countries in South America [3]. This infection must be differentiated from other causes of similar symptoms. Person-to-person transmission has been described in Argentina [4-6] and could not be excluded in two Andes virus-related family clusters from Chile [7], thus early diagnosis is crucial to prevent outbreaks and to perform a strict clinical follow-up of contacts. It has been considered desirable

Received 9 Feb. 1999; revised version accepted 25 June 1999.

Corresponding author: Dr P. J. Padula. for confirmed cases of Andes virus infection to be isolated in separate care units and for 'droplet precautions' to be used [7]. In addition there are ongoing trials of antiviral therapies for known contacts.

Highly sensitive reagents are also important for assessing the seroprevalence of this virus in man and rodents. The association of hantaviruses with different rodent reservoirs in several geographic areas suggests that development of region-specific antigens should be undertaken to improve serological reactivity. As for other viruses, the use of the homologous antigen improves the sensitivity and specificity of the assays, providing earlier antibody detection in infected people [8-11]. Thus, some of the South A merican viruses may give higher optical density readings in enzyme-linked immunosorbent assays (ELISA) with reagents based on the local viral sequence [12].

The viral nucleoprotein (N) elicits a strong humoral 
immune response in infected patients and immunised animals [13-15] and has been used extensively to produce diagnostic reagents for hantaviruses $[8,16-$ 18].

In phylogenetic analysis, all viruses associated with cases of HPS from Argentina [6, 19], Chile [20], Paraguay [21] and U ruguay (P. J. Padula, unpublished observations) and sigmodontine-related virus from Bolivia [22, 23], clustered together with Andes virus [24] and some North American viruses like Sin Nombre (SN) $[2,25]$, Bayou (BAY) [26] or Black Creek Canal (BCC) [27].

Human exposure to hantaviruses occurs principally through the respiratory tract route; thus, mucosal inmunity may confer the first line of defence against infection, as has been suggested in influenza virus infection [28] and confirmed by in-vitro studies [29]. However, secretory IgA response has not been assessed in hantavirus-infected patients.

An Andes virus sample was used to produce a recombinant antigen to detect $\operatorname{IgM}$ antibodies against hantavirus by capture ELISA and IgG or IgA antibodies by direct ELISA. This reagent was evaluated to establish its utility for hantavirus diagnosis in serum or saliva from acute and early convalescent patients and its application in human and rodent seroprevalence studies in affected areas of South A merica.

\section{$M$ aterials and methods}

\section{Samples from patients and rodents}

Routine serum samples from patients with suspected HPS from Argentina, Chile, Paraguay and U ruguay were received over a 2-year period. One hundred and seventy-three serum samples from 135 hantavirusspecific reverse transcription (RT)-PCR-positive patients were tested for hantavirus antibodies by $\mu$ capture IgM ELISA, and IgG and IgA ELISA. Eight saliva samples were studied by IgA ELISA. Seroprevalence studies from an endemic region (Salta, north A rgentina; $n=57$ subjects) and from a non-endemic city (Buenos Aires; $\mathrm{n}=210$ subjects) were also conducted.

Hantavirus antisera developed in rodents live-trapped primarily in rural and peri-domestic habitats in northern and southern regions of Argentina were investigated for Andes-specific IgG.

\section{Control samples}

Fifty saliva samples and 190 sera collected from apparently healthy adults and 45 sera from healthy children not living in endemic areas were used to investigate the specificity of the assays. Also, $455 \mathrm{HPS}$ contacts without disease were studied. Serum samples from people who had been infected with: Chlamydia spp. $(n=14)$, Leptospira interrogans (11), Legionella spp. (5), Mycoplasma pneumoniae (9), Junin virus (Argentine haemorrhagic fever) (20), influenza $A$ and $B$ (18), were also tested. Sera were kept at $-20^{\circ} \mathrm{C}$ until analysis.

\section{Preparation of antigens}

Based upon the Andes $S$ segment sequence, PCR primers were designed flanked by appropriate restriction endonuclease sites, to allow the cloning and expression of the Andes $\mathrm{N}$ gene. Total RNA extraction, RT-PCR amplification and sequencing were performed as described previously [20].

The Andes $\mathrm{N}$ gene was amplified in a 'hemi-nested' fashion with the following primers: +5 (5'-AGTAGACTCCTTGAGAAGCTAC- $\left.3^{\prime}\right)$, +22 (5'-GCTACTACGACTAAAGCTGGAATGAG-3'), - 1554 (5'-TA TAGACTAACCCACCTCCC-3').

The DNA fragment containing the $N$ protein ORF was cloned in PRSET A vector according to the manufacturer's instructions ( $\& \& D$ Systems Europe, Oxford). The recombinant clone was used to transform Escherichia coli BL21 (DE3) cells. Expression was obtained without induction. Cells were harvested by centrifugation at $5000 \mathrm{~g}$ for $20 \mathrm{~min}$ and were resuspended in lysis buffer ( $50 \mathrm{~mm}$ Tris- $\mathrm{HCl}$, pH 7.5, 0.5 mM EDTA, $0.3 \mathrm{M}$ $\mathrm{NaCl}$, lysozyme $0.01 \%$ and Triton X-100 $0.1 \%$ ), centrifuged and resuspended in a denaturation buffer (50 mM Tris- $\mathrm{HCl}, \mathrm{pH} 7.5,6 \mathrm{M}$ urea, $\beta$-mercaptoethanol $1 \%$ and SDS 1\%). The pellet was recovered and processed on a nickel resin affinity column (Ni-NTA agarose provided by Quiagen, Gmbtt Hilden, Germany).

A recombinant opposite sense-encoding $\mathrm{N}$ protein was expressed in the same manner and was used as negative control antigen.

\section{Amino acid comparison}

The following published $\mathrm{S}$ segment sequences were used for amino acid comparisons:

A ndes virus (AND) [20], A F004660; Chile (CH-1/96) [20], AF005941, AF005945, AF005947; Uruguay (URU-3) (submitted to Gene Bank); Laguna Negra virus (LN) [21], A F005727; Rio Mamore virus (RIOM) [23], U52136; Caño Delgadito virus (CDG) [11], AF000140; Rio Segundo virus (RIOS) [30], U18100; Bayou virus (BAY) [26], L36929; B lack Creek Canal virus (BCC) [27], L39949; Sin Nombre virus (SN) [31], L37904.

Multiple sequence alignment and comparison of deduced amino-acid sequences were performed with CLUSTAL V, programs of the PCGENE 6.8 software, Intelligenetics (M ountain View, CA, USA). 
Immunisation procedure

Rabbits, weighing an average of $2 \mathrm{~kg}$, were inoculated subcutaneously with multiple injections three times at 15-day intervals with $200 \mu \mathrm{g}$ of Andes $\mathrm{N}$ purified protein. Serum was obtained 20 days after the last immunisation. The reactivity of the serum was checked by IgG ELISA. Immunoblotting was used to characterise the antigen population against which specific antibodies had been raised [32].

\section{$\mu$-Capture IgM ELISA technique}

Serial dilutions of all reagents were tested in various combinations to achieve the clearest separation of Andes IgM seropositive and negative samples. All reagents were added in $0.1-\mathrm{ml}$ volumes. Highly activated flat-bottomed polystyrene microtitration plates (Certified Maxisorp, Nunc) or U-bottomed polyvinylchloride microtitration plates (Falcon) were coated with a 1 in 1000 dilution of an affinity-purified goat antihuman IgM $(\mu)$ antibody (K ierkegaard and Perry) in $0.1 \mathrm{M}$ carbonate buffer, $\mathrm{pH}$ 9.5. All the following incubations were done at $37^{\circ} \mathrm{C}$ for $1 \mathrm{~h}$ and the plates were washed six times in wash buffer (Tween-20 0.1\% in PBS) between each step.

Serum samples diluted 1 in 100 and four-fold up to 1 in 6400 in dilution buffer (skimmed milk powder $5 \%$ in PBS-Tween-20) were allowed to react with the antihuman IgM $(\mu)$ antibody-coated wells. Recombinant Andes and control antigen diluted in dilution buffer at a concentration of $2 \mu \mathrm{g} / \mathrm{ml}$ were allowed to react with the specific binding antibodies. Subsequently, a 1 in 25000 dilution of rabbit hyperimmune serum in dilution buffer was added. The addition of a 1 in 5000 dilution of hantavirus antibody-negative human serum to each antigen preparation and to the conjugated serum before they were added to the plate served to block any open capture antibody sites and kept background signals low. Goat anti-rabbit serum conjugated to alkaline peroxidase (K ierkegaard and Perry) (1 in 5000 in dilution buffer) was then added. Finally, ABTS (2.2'-azino-di [3-ethyl-benzthiazoline sulphonate (6)] substrate (K ierkegaard and Perry) was added and absorbance at $405 \mathrm{~nm}$ was measured with a BioRad 550 microplate reader. The values were expressed as the optical density (OD) obtained with Andes antigen substracted from the OD of the control antigen.

\section{IgG and IgA ELISA techniques}

Polystyrene microtitration plates (Polysorp, Nunc) or $\mathrm{U}$-bottomed polyvinylchloride microtitration plates (Falcon) were coated with $\mathrm{N}$ A ndes antigen and control antigen, at concentrations of $4 \mu \mathrm{g} / \mathrm{ml}$ and $0.4 \mu \mathrm{g} / \mathrm{ml}$, respectively, diluted in $0.1 \mathrm{M}$ sodium carbonate buffer, $\mathrm{pH}$ 9.5. Patient and control sera diluted 1 in 100 in dilution buffer and four-fold up to 1 in 6400 or saliva diluted 1 in 16 and two-fold up to 1 in 64 were added to the antigen-coated wells. Sera were diluted up to 1 in 102400 for titration tests. The plates were incubated at $37^{\circ} \mathrm{C}$ for $1 \mathrm{~h}$ and washed as for $\mu$-capture IgM ELISA. Peroxidase-labelled affinity-purified goat antihuman IgG $(\mathrm{Fc})$ or peroxidase-labelled affinity-purified goat anti-human IgA $(\alpha)$ antibody (K ierkegaard and Perry) (1 in 3000 in dilution buffer) were added and specific antibody binding was detected by ABTS substrate. To remove IgG present in sera for performing the IgA test, $25 \mu \mathrm{l}$ of each serum were mixed with $100 \mu \mathrm{l}$ of a $50 \%$ suspension of Gamma-bind $\mathrm{G}$ agarose beads (Protein $G$ Sepharose, Pharmacia) and incubated as recommended by the manufacturer.

Preparations of 1 in 200 and 1 in 400 in dilution buffer and peroxidase-labelled affinity-purified antibody to Peromyscus leucopus IgG $(\mathrm{H}+\mathrm{L})$ (K ierkegaard and Perry) (1 in 2000 in dilution buffer) were used for rodent serum assays.

The OD values were expressed as for the IgM technique.

\section{Results}

Amino-acid sequence comparison of hantavirus $\mathrm{N}$ proteins

To evaluate the convenience of using Andes $\mathrm{N}$ recombinant protein as an immunodiagnostic antigen, the study compared the amino-acid identity between putative $\mathrm{N}$ proteins of representative HPS viruses.

Although the amino-acid sequences of 10 HPS hantaviruses from the Americas showed a degree of identity $>79.1 \%$, when Andes $\mathrm{N}$ protein virus was compared with others from South A merica the values ranged from $84.3 \%$ with CDG from Venezuela to $98 \%$ with Chilean virus (Table 1). Comparison between partial $\mathrm{N}$ protein sequences belonging to Argentine central region genotypes and $\mathrm{Andes} \mathrm{AH}-1$ strain showed amino acid identities of nearly $94 \%$ (data not shown).

\section{Cloning expression and purification of Andes virus $N$ ORF frame}

Nucleotide sequence of the expression vector constructs identified the corresponding published sequence. The predicted fusion protein expressed by this vector should have a mol. wt of $54 \mathrm{kDa}$, which includes six aminoterminal histidine residues for convenient affinity purification. Gel electrophoresis on SDS 10\% polyacrylamide gels revealed highly purified recombinant protein of the expected size (Fig. 1, lane 1). The yield of recombinant proteins ranged from 16 to $24 \mathrm{mg} / \mathrm{L}$ of culture for four different batches and that of the purified antigen ranged from 9 to $14 \mathrm{mg} / \mathrm{L}$. 
Table 1. Percentage amino-acid (aa) sequence identity between $\mathrm{N}$ proteins of South and North A merican sigmodontine hantaviruses

\begin{tabular}{|c|c|c|c|c|c|c|c|c|c|c|}
\hline & $\begin{array}{c}\text { AND* } \\
\text { A rgentina }\end{array}$ & $\begin{array}{l}\text { URU-3* } \\
\text { Uruguay }\end{array}$ & $\begin{array}{c}\mathrm{CH}-1 / 96^{*} \\
\text { Chile }\end{array}$ & $\begin{array}{c}\mathrm{LN}^{*} \\
\text { Paraguay }\end{array}$ & $\begin{array}{l}\text { RIOM } \\
\text { Bolivia }\end{array}$ & $\begin{array}{c}\text { CDG* } \\
\text { Venezuela }\end{array}$ & $\begin{array}{c}\text { RIOS } \\
\text { Costa Rica }\end{array}$ & $\begin{array}{l}\text { BAY* } \\
\text { USA }\end{array}$ & $\begin{array}{l}\text { BCC* } \\
\text { USA }\end{array}$ & $\begin{array}{l}\text { SN* } \\
\text { USA }\end{array}$ \\
\hline $\begin{array}{l}\text { AND A rgentina } \\
\text { URU-3 Uruguay } \\
\text { CH-1/96 Chile } \\
\text { LN Paraguay } \\
\text { RIOM Bolivia } \\
\text { CDG Venezuela } \\
\text { RIOS Costa Rica } \\
\text { BAY USA } \\
\text { BCC USA } \\
\text { SN USA }\end{array}$ & & 95.3 & $\begin{array}{l}98.3 \\
92.0\end{array}$ & $\begin{array}{l}90.4 \\
86.4 \\
87.0\end{array}$ & $\begin{array}{l}91.1 \\
87.4 \\
88.3 \\
93.2\end{array}$ & $\begin{array}{l}84.3 \\
82.1 \\
81.3 \\
83.2 \\
83.5\end{array}$ & $\begin{array}{l}81.8 \\
79.1 \\
79.7 \\
80.6 \\
81.5 \\
79.8\end{array}$ & $\begin{array}{l}88.3 \\
85.7 \\
86.3 \\
87.1 \\
88.1 \\
81.6 \\
83.6\end{array}$ & $\begin{array}{l}86.4 \\
83.1 \\
84.3 \\
85.5 \\
86.7 \\
80.9 \\
92.0 \\
92.3\end{array}$ & $\begin{array}{l}86.0 \\
85.0 \\
83.7 \\
85.3 \\
84.6 \\
83.2 \\
83.2 \\
86.9 \\
83.9\end{array}$ \\
\hline
\end{tabular}

All compared sequences were 428 aa in length, except for CH-1/96 (300 aa), URU-3 (301 aa) and CDG (376 aa).

*Hantaviruses associated with human disease.

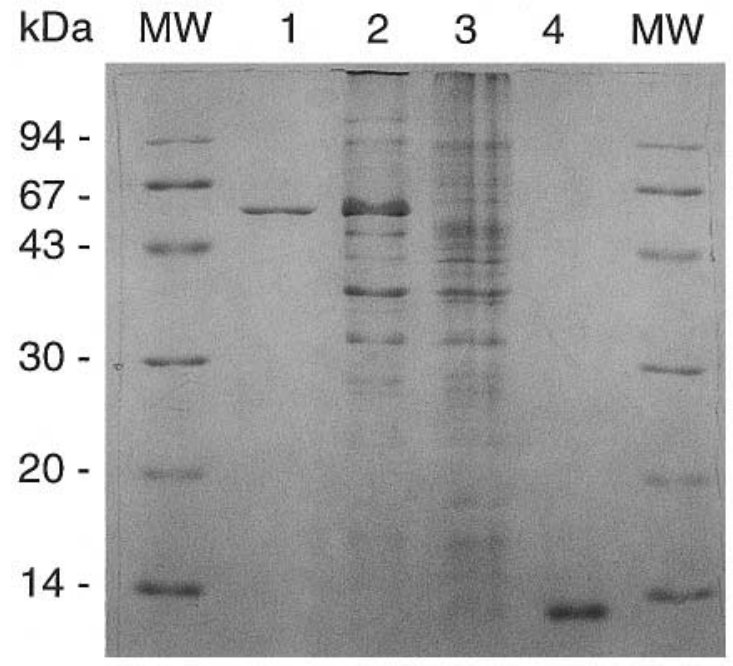

Fig. 1. Polyacrylamide gel electrophoresis of Andes virus fusion proteins produced in E. coli. Recombinant Andes $\mathrm{N}$ protein (land 1) and recombinant opposite senseencoding $\mathrm{N}$ protein (4) after purification by Ni-NTA column chromatography; total cellular proteins of the $\mathrm{N}$ protein expression clone (2); crude cell lysate of untransformed cells (3). The numbers correspond to the mol. wt (M W).

The identity of the protein expressed by the transformants after purification by chromatography was confirmed by immunoblot analysis with sera from Andes virus-infected patients and negative control sera where the unique expected band was observed. The recombinant opposite sense-encoding $\mathrm{N}$ protein expressed by the transformants showed no reactivity with these sera (data not shown).

Hantavirus IgG, IgM and IgA responses of HPS from South America

A total of 173 sera from 135 patients with confirmed HPS was studied to evaluate the reagent. All specimens were tested in duplicate with $\mathrm{N}$ Andes antigen and also with negative control antigen. Hantavirus RNA detection by PCR and the broad detectable reactive antibodies specific for the Andes virus nucleocapsid protein by $\mu$-capture IgM ELISA showed 100\% correlation of diagnosis in the patients studied.

Specific IgM antibodies were detected in acute- and early convalescent-phase specimens in sera from A rgentina, Chile, Uruguay and Paraguay in the first sample available as early as 1 or 2 days after the onset of symptoms. An IgG response was detected mostly after the first week, although some sera were reactive at the onset (Table 2). Increase of IgG antibody titres was observed between the first sample (days 1-9) and the

Table 2. $\mu$-capture IgM and direct ELISA IgG and IgA antibody detection in serum samples from patients with HPS

\begin{tabular}{|c|c|c|c|}
\hline \multirow{2}{*}{$\begin{array}{l}\text { Days after } \\
\text { onset of } \\
\text { symptoms }\end{array}$} & \multicolumn{3}{|c|}{ Number of patients (positive/total) in ELISA for } \\
\hline & $\lg M$ & IgG & $\lg A$ \\
\hline 1 & $4 / 4$ & $1 / 4$ & $2 / 2$ \\
\hline 2 & $12 / 12$ & $8 / 12$ & $7 / 7$ \\
\hline 3 & $11 / 11$ & $6 / 11$ & $6 / 8$ \\
\hline 4 & $20 / 20$ & $13 / 20$ & $12 / 15$ \\
\hline 5 & $14 / 14$ & $10 / 14$ & $8 / 10$ \\
\hline 6 & $16 / 16$ & $12 / 16$ & $9 / 9$ \\
\hline 7 & $17 / 17$ & $14 / 17$ & $10 / 11$ \\
\hline 8 & $7 / 7$ & $7 / 7$ & $6 / 6$ \\
\hline 9 & $2 / 2$ & $2 / 2$ & $1 / 1$ \\
\hline 10 & $6 / 6$ & $4 / 6$ & $3 / 5$ \\
\hline 11 & $4 / 4$ & $3 / 4$ & $4 / 4$ \\
\hline 12 & $2 / 2$ & $2 / 2$ & $2 / 2$ \\
\hline 13 & $2 / 2$ & $1 / 2$ & $1 / 1$ \\
\hline 14 & $6 / 6$ & $6 / 6$ & $2 / 3$ \\
\hline 15 & $2 / 2$ & $2 / 2$ & $1 / 1$ \\
\hline 16 & $6 / 6$ & $5 / 6$ & $4 / 5$ \\
\hline 17 & $3 / 3$ & $3 / 3$ & $4 / 4$ \\
\hline 18 & $1 / 2$ & $2 / 2$ & $1 / 1$ \\
\hline 20 & $2 / 3$ & $3 / 3$ & $3 / 3$ \\
\hline 21 & $2 / 2$ & $2 / 2$ & $1 / 1$ \\
\hline 22 & $2 / 2$ & $2 / 2$ & $2 / 2$ \\
\hline 23 & $3 / 3$ & $3 / 3$ & $1 / 1$ \\
\hline 24 & $1 / 1$ & $1 / 1$ & $1 / 1$ \\
\hline 30 & $1 / 1$ & $1 / 1$ & $0 / 1$ \\
\hline 31 & $2 / 2$ & $2 / 2$ & $1 / 1$ \\
\hline 32 & $1 / 1$ & $1 / 1$ & $1 / 1$ \\
\hline 36 & $1 / 1$ & $1 / 1$ & $1 / 1$ \\
\hline 42 & $1 / 1$ & $1 / 1$ & $1 / 1$ \\
\hline 44 & $0 / 1$ & $1 / 1$ & $0 / 1$ \\
\hline $45-87$ & $4 / 13$ & $13 / 13$ & $6 / 7$ \\
\hline $124-195$ & $0 / 6$ & $6 / 6$ & $2 / 4$ \\
\hline Total & $155 / 173$ & $138 / 173$ & $103 / 120$ \\
\hline
\end{tabular}

Sera with OD $>0.3$ were considered positive. 
second sample (days 18-40) in 29 of 30 individuals from whom paired sera were obtained. Seroconversion was observed in at least 15 cases. Thirty days after the onset, I gG titres were $>25600$ in most of the cases. No decrease in IgG antibody titres was observed during the study period.

Some early Andes IgG-ELISA seropositive samples were negative with SN antigen; however, subsequent samples from these patients reacted with both reagents (N. Pini, unpublished results).

In contrast, 455 case contacts, without HPS symptoms, were negative for $\mu$-capture IgM and IgG antibodies when analysed within 7 days (345 serum samples) and 60 days (217 serum samples) after the onset of symptoms in the HPS case.

The IgA response peaked at c. 1-2 weeks after onset of symptoms. Ninety-one (87.5\%) of 104 samples obtained up to 30 days after onset had specific serum IgA antibodies. No significant differences were found when latex was used for IgG adsorption. Seven of nine saliva samples from eight patients with HPS had detectable specific saliva IgA antibodies from day 5 and within a month after the onset of symptoms (Table 3).

The reagent was used to study seroprevalence in three Argentine regions. In a non-epidemic area (Buenos Aires City), none of 210 sera was positive. In the southern region where person-to-person transmission was demonstrated [6], the seropositive percentage was $0.6 \%(n=470)$ [33]. In workers living in a rural sugar refinery in the Salta province of Argentina, seroprevalence was $5.1 \%(n=57)$. These latter two were both endemic areas. No equivocal test result was found in this seroprevalence study, although lower IgG titres (1400-6400) were obtained when compared with sera from HPS patients.

\section{Specificity and sensitivity of the ELISA assays}

To evaluate the specificity of the assays, sera and saliva samples from healthy adults and children not living in endemic areas and from subjects with other respiratory infections and haemorrhagic diseases were tested for Andes virus-specific IgM, IgG and IgA antibodies.

All sera were tested with Andes antigen and control antigen and none was reactive. A malaria parasitepositive individual with compatible symptoms of hantavirus infection gave a high signal with the recombinant opposite sense-encoding $\mathrm{N}$ protein, although the final result was negative.

The specificity and sensitivity of the IgM and IgG assays in early and convalescent samples were $100 \%$.

The coefficients of inter-assay variation were 11.6, 9.1 and $\mathbf{1 3 . 0}$ for IgM, IgG and IgA, respectively. The negative media OD values were $0.06,0.03,0.04$ and the positive $O D$ values were 2.7, 2.8, 2.8 for IgM, IgG and IgA ELISA, respectively, at 1 in 400 serum dilution.

\section{Protein Andes $\mathrm{N}$ reactivity of animal sera}

Sera from several species of rodents were examined in this study. ELISA antibodies were detected most frequently in sera from Oligoryzomys longicaudatus with an overall antibody prevalence rate of $4.15 \%$ $(n=193)$. However, antibody was not restricted to this species. 0 . chacoensis and 0 . flavescens were also frequently positive. Sera from individual animals of these two species had high antibody titres by ELISA (6400) and were clearly true positive RT-PCR reactions. However, RT-PCR performed on lungs of 20 seronegative 0 . longicaudatus selected at random gave negative results.

Two seropositive rodents from other genera, one Akodon various and one Abrothix longipilis, were negative by RT-PCR reactions.

\section{Discussion}

At present, the optimal test for diagnosis of acute HPS is the $\mu$-capture IgM ELISA [12]. Serological

Table 3. ELISA IgA antibodies in saliva from HPS patients by day of disease

\begin{tabular}{lcccc}
\hline \multirow{2}{*}{$\begin{array}{l}\text { HPS patient } \\
\text { no. }\end{array}$} & $\begin{array}{c}\text { Days after } \\
\text { onset of } \\
\text { symptoms }\end{array}$ & 1 in 16 & 1 in 32 & 1 in 64 \\
\cline { 3 - 5 } & 3 & 0.19 & 0.13 & 0.08 \\
1 & 5 & 0.97 & 0.51 & 0.24 \\
3 & 7 & 1.78 & 0.67 & 0.14 \\
& 16 & 3.14 & 2.33 & 1.3 \\
4 & 10 & 0.83 & 0.48 & 0.22 \\
5 & 16 & 1.65 & 1.41 & 0.76 \\
6 & 17 & 1.02 & 0.52 & 0.32 \\
7 & 31 & 0.99 & 0.63 & 0.29 \\
8 & 36 & 0.13 & 0.09 & 0.06 \\
Negative control & - & $0.049(0.06)^{\dagger}$ & $0.019(0.02)$ & $0.015(0.009)$ \\
\hline
\end{tabular}

*Mean OD from three independent tests.

${ }^{\dagger} M$ ean OD (SD) of saliva samples from 50 healthy subjects. 
confirmation with this assay can usually be made with a single serum sample, as specific IgM antibodies are detectable shortly after onset of clinical HPS symptoms.

The outbreak of HPS cases in South America was associated with the Andes and closely related viruses. The choice of Andes $\mathrm{N}$ protein provided the opportunity to express a good predictive recombinant specific antigen to improve the diagnostic capabilities for South A merican cases of HPS. Comparison of HPS virus N protein sequences of the region with the corresponding sequences of representative sigmodontine hantaviruses showed the highest degree of similarity with that of Andes virus in most of the cases.

IgM ELISA results from the first available sample from HPS cases showed $100 \%$ sensitivity and specificity, as well as excellent reproducibility. Specific IgM antibodies were present for $>1$ month following the onset of disease. Sera from 190 healthy individuals were examined and there were no false positive samples by IgM capture or IgG ELISA. Specific IgG antibodies were detected in all sera from convalescent patients. The consistent IgG antibody detection obtained in late samples from all HPS case and from seroprevalence studies may show that this test is helpful for epidemiological studies.

Although native hantavirus antigens are being used widely as diagnostic reagents, their production requires expensive containment laboratory conditions for virus propagation. Recombinant protein technology is less expensive and proteins are generated in larger amounts and with higher purity than native viral antigens. The successful use of recombinant $\mathrm{N}$ antigen in the IgM capture assay, with high sensitivity and specificity, for diagnosis of HPS in different regions and countries shows that this approach is feasible in practice.

IgG antibody detection is especially useful for rodent serosurveys and has played an integral part in establishing the reservoir host and studying the natural ecology of the virus. Detection of antibodies against A ndes $\mathrm{N}$ protein in sera from different rodent species in our region showed that this study may be used with high efficiency in rodent seroprevalence assays. A significant number of rodent sera gave positive reactions in ELISA with Andes antigen and negative reactions when SN antigen was used (N. Pini, personal communication).

Recently it has been reported that the ratio of the ELISA values obtained with SN versus Puumala virus protein as antigen increased with time after onset of disease in Puumala-infected patients [34]. Thus the use of homologous antigens becomes more important when acutely infected patients are being studied. Careful optimisation and validation of this test will ensure that there is no loss of sensitivity or specificity when used in cases from distant regions.
The widespread distribution of A ndes-related viruses in different rodent species [19] raises the possibility that HPS may well exist undiagnosed in regions of South A merica beyond its traditionally recognised enzootic boundaries.

Determination of specific antibodies in saliva samples makes this test even more useful for isolated communities and, especially among some native populations of South America who, due to cultural reasons, do not always accept venepuncture. As human infection occurs via inhalation of contaminated aerosol, secretory IgA could provide effective protection against hantavirus infection.

The high mortality rate observed in infected patients $[2,12,35]$, the short duration of the disease and the risk to contacts caused by person-to-person transmission necessitate the use of more sensitive tests which might lead to earlier detection of infected people and improve the treatment and management of HPS patients.

We are indebted to: J. Mora Riquelme Inst. de Salud Pública from Chile; N. Colucchi Lab. Central de Salud Pública and M. Almiron Inst. de Investig. en Cs. de la Salud from Paraguay; J. Russi Div Lab. de Salud M inisterio de Salud Pública from U ruguay for their opinions and materials. We gratefully acknowledge the contributions of all physicians and epidemiologists who took care of the patients for their data and views; and special thanks to María Cristina Oses for technical support.

\section{References}

1. Schmaljohn C, Hjelle B. Hantaviruses: a global disease problem. Emerg Infect Dis 1997; 3: 95-104.

2. Nichol ST, Spiropoulou CF, Morzunov $S$ et al. Genetic identification of a hantavirus associated with an outbreak of acute respiratory illness. Science 1993; 262: 914-917.

3. Pan A merican Health Organization. Hantavirus in the A mericas: Guidelines for diagnosis, treatment, prevention and control. 1998 Task Force M eeting, A tlanta, 7-8 M arch, 1998.

4. Enria D, Padula PJ, Segura EL et al. Hantavirus pulmonary syndrome in Argentina. Possibility of person-to-person transmission. Medicina B Aires 1996; 56: 709-711.

5. Wells RM, Sosa Estani S, Yadón ZE et al. An unusual hantavirus outbreak in Southern Argentina: person-to-person transmission? Hantavirus Pulmonary Syndrome Study Group for Patagonia. Emerg Infect Dis 1997; 3: 171-174.

6. Padula PJ, Edelstein A, Miguel SDL, López NM, Rossi CM, Rabinovich RD. Hantavirus pulmonary syndrome outbreak in A rgentina: molecular evidence for person-to-person transmission of Andes virus. Virology 1998; 241: 323-330.

7. Toro J, Vega JD, K han AS et al. An outbreak of hantavirus pulmonary syndrome, Chile, 1997. Emerg Infect Dis 1998; 4: 687-694.

8. Feldmann $H$, Sanchez A, Morzunov $S$ et al. Utilization of autopsy RNA for the synthesis of the nucleocapsid antigen of a newly recognized virus associated with hantavirus pulmonary syndrome. Virus Ręs 1993; 30: 351- 367.

9. Elgh $F$, Lundkvist A, Alexeyev $O A$ et al. Serological diagnosis of hantavirus infections by an enzyme-linked immunosorbent assay based on detection of immunoglobulin $G$ and $M$ responses to recombinant nucleocapsid proteins of five viral serotypes. J Clin Microbiol 1997; 35: 1122-1130.

10. Wang M, Rossi C, Schmaljohn CS. Expression of nonconserved regions of the $S$ genome segment of three hantaviruses: evaluation of the expressed polypeptides for diagnosis of haemorrhagic fever with renal syndrome. J Gen Virol 1993; 74: 1115-1124. 
11. Fulhorst CF, Monroe MC, Salas RA et al. Isolation, characterization and geographic distribution of Caño Delgadito virus, a newly discovered South A merican hantavirus (family Bunyaviridae). Virus Res 1997; 51: 159-171.

12. Peters CJ. Hantavirus Pulmonary Syndrome in the Americas. Emerg Infect Dis 1998; 2: 17-64.

13. Elgh $F$, Linderholm $M$, Wadell $G$, Juto $P$. The clinical usefulness of Puumala virus recombinant nucleocapsid protein based enzyme-linked immunosorbent assay in the diagnosis of nephropathia epidemica as compared to an immunofluorescence assay. Clin Diagn Virol 1996; 6: 17-26.

14. Elgh $F$, Wadell $G$, Juto P. Comparison of the kinetics of Puumala virus specific IgM and IgG antibody responses in nephropathia epidemica as measured by a recombinant antigenbased enzyme-linked immunosorbent assay and an immunofluorescence test. J Med Virol 1995; 45: 146-150.

15. Lundkvist A, Hörling J, Nilkasson B. The humoral response to Puumala virus infection (nephropathia epidemica) investigated by viral protein specific immunoassays. Arch Virol 1993; 130: 121- 130.

16. Kallio-Kokko $H$, Vapalahti $O$, Lundkvist $A$, Vaheri. Evaluation of Puumala virus IgG and IgM enzyme immunoassays based on recombinant baculovirus-expressed nucleocapsid protein for early nephropathia epidemica diagnosis. Clin Diagn Virol 1998; 10: 83-90.

17. Zöller L, Yang S, Gött P, Bautz EKF, Darai G. Use of recombinant nucleocapsid proteins of the Hantaan and nephropathia epidemica serotypes of Hantaviruses as immunodiagnostic antigens. J Med Virol 1993; 39: 200-207.

18. Zöller LG, Yang S, Gött $P, B$ autz EKF, Darai $G$. A novel $\mu$-capture enzyme-linked immunosorbent assay based on recombinant proteins for sensitive and specific diagnosis of hemorrhagic fever with renal syndrome. J Clin Microbiol 1993; 31: 1194-1199.

19. Levis S, Morzunov SP, Rowe JE et al. Genetic diversity and epidemiology of hantaviruses in A rgentina. J Infect Dis 1998; 177: $529-538$

20. López N, Padula P, Rossi C et al. Genetic characterization and phylogeny of Andes virus and variants from Argentina and Chile. Virus Res 1997; 50: 77-84.

21. Johnson $A M$, Bowen MD, Ksiazek TG et al. Laguna Negra virus associated with HPS in Western Paraguay and Bolivia. Virology 1997; 238: 115-127.

22. Hjelle B, Torrez-M artínez N, Koster FT. Hantavirus pulmonary syndrome-related virus from Bolivia. Lancet 1996; 347: 57.

23. Bharadwaj M, Botten J, Torrez-Martínez N, Hjelle B. Río $M$ amore virus: genetic characterization of a newly recognized hantavirus of the pygmy rice rat, Oligoryzomys microtis, from
Bolivia. Am J Trop Med Hyg 1997; 57: 368-374.

24. López $N$, Padula $P$, Rossi $C$, Lázaro $M E$, Franze-Fernández MT. Genetic identification of a new hantavirus causing severe pulmonary syndrome in A rgentina. Virology 1996; 220: 223226.

25. Spiropoulou CF, Morzunov S, Feldman H, Sanchez A, Peters C), Nichol ST. Genome structure and variability of a virus causing hantavirus pulmonary syndrome. Virology 1994; 200: 715- 723.

26. M orzunov SP, Feldmann $H$, Spiropoulou $C F$ et al. A newly recognized virus associated with a fatal case of hantavirus pulmonary syndrome in Louisiana. J Virol 1995; 69: 19801983.

27. Ravkov EV, Rollin PE, K siazek TG, Peters CJ, Nichol ST. Genetic and serologic analysis of Black Creek Canal virus and its association with human disease and Sigmodom hispidus infection. Virology 1995; 210: 482-489.

28. Welliver RC. Respiratory infections In: Ogra PL, Strober W Mestecky J, McGhee JR, Lamm ME, Bienenstock J (eds) Handbook of mucosal immunology. San Diego, Academic Press. 1994: 551-559.

29. Renegar K B, Jackson GDF, M estecky J. In vitro comparison of the biologic activities of monoclonal monomeric IgA, polymeric IgA, and secretory IgA . I Immunol 1998; 160: 1219-1223.

30. Hjelle B, Anderson B, Torrez-Martinez N, Song W, Gannon $W L$, Yates TL. Prevalence and geographic genetic variation of hantaviruses of New World harvest mice (Reithrodontomys): identification of a divergent genotype from Costa Rican Reithrodontomys mexicanus. Virology 1995; 207: 452- 459.

31. Chizhikov VE, Spiropoulou CF, M orzunov SP, Monroe MC Peters CJ, Nichol ST. Complete genetic characterization and analysis of isolation of Sin Nombre virus. J Virol 1995; 69: 8132- 8136

32. Towbin H, Stahlelin T, Gordon J. Electrophoretic transfer of proteins from polyacrylamide gels to nitrocellulose sheets: Procedure and some applications. Proc Natl Acad Sci USA 1979; 76: 4350- 4354.

33. Wells RM, Sosa Estani S, Yadón ZE et al. Seroprevalence of antibodies to hantavirus in health care workers and other residents of southern Argentina. Clin Infect Dis 1998; 27: 895- 896.

34. Elgh F, Linderholm M, Wadell G, Tarnvik A, Juto $P$. Development of humoral cross-reactivity to the nucleocapsid protein of heterologous hantaviruses in nephropathia epidemica. FEMS Immunol Med Microbiol 1998; 22: 309-315.

35. K siazek TG, Peters CJ, Rollin PE et al. Identification of a new North American hantavirus that causes acute pulmonary insufficiency. Am J Trop Med Hyg 1995; 52: 117- 123. 